\title{
Application of MAP and ethylene-vinyl alcohol copolymer (EVOH) to extend the shelf-life of green and white asparagus (Asparagus officinalis L.) spears
}

\author{
Magdalena Gantner ${ }^{1} \cdot$ Katarzyna Król $^{1} \cdot$ Klaudia Kopczyńska $^{1}$
}

Received: 16 September 2019 / Accepted: 30 March 2020 / Published online: 4 April 2020

(c) The Author(s) 2020

\begin{abstract}
In this study, ethylene vinyl alcohol copolymer (EVOH) and polypropylene/polyethylene (PP/PE) films combined with MAP packaging were developed to enhance the shelf-life of green and white asparagus spears. The scope of the research included measurements of weight loss, $\mathrm{pH}$, acidity, color, texture, and sensory analysis as indicators of green and white asparagus spear quality for up to 17 days of storage at 2 and $10{ }^{\circ} \mathrm{C}$. The application of modified atmosphere packaging combined with EVOH-based packaging material and refrigeration at $2{ }^{\circ} \mathrm{C}$ promoted a reduction in asparagus weight loss, preventing changes in color and texture as well as sensory quality, thereby extending the shelf-life of the asparagus. According to the obtained results, it was possible to maintain good quality of green and white asparagus for up to 17 and 10 days, respectively, when packed in MAP using EVOH-based packaging stored at $2{ }^{\circ} \mathrm{C}$. Asparagus stored in packaging with PP/PE film showed lower quality during storage at 2 and $10^{\circ} \mathrm{C}$. These results suggest that EVOH films are potential candidates for advanced packaging materials for the asparagus packaging application.
\end{abstract}

Keywords Asparagus $\cdot$ Shelf-life $\cdot \mathrm{PP} / \mathrm{EVOH} / \mathrm{PE} \cdot \mathrm{PP} / \mathrm{PE} \cdot$ Modified atmosphere packaging

\section{Introduction}

Asparagus (Asparagus officinalis L.) has been increasingly consumed due to its high nutritional and low-calorie value. Compared to white asparagus, green asparagus has a higher nutritional value and contains almost 20 times more vitamin A, 2 times more vitamin B and 2 times more vitamin $\mathrm{C}$, while white asparagus contains 1.5 times more protein [1]. In general, asparagus spears are rich sources of carbohydrates (sucrose, fructose, and glucose insoluble sugars), which affect the lignification process [2]. Reports have shown that, consumption of this vegetable or food products

Electronic supplementary material The online version of this article (https://doi.org/10.1007/s11694-020-00449-6) contains supplementary material, which is available to authorized users.

Katarzyna Król

katarzyna_krol@sggw.pl

1 Department of Functional and Organic Food, Institute of Human Nutrition Sciences, Warsaw University of Life Sciences, Nowoursynowska 159c, 02-776 Warsaw, Poland supplemented with asparagus spear extracts may help treat digestive disorders, cardiovascular diseases and diabetes [3].

Asparagus has a short shelf-life (3-5 days) due to its high respiration rate, which continues after harvesting. The high respiration rate leads to high sensitivity of asparagus during storage, and rapid quality deterioration. The loss of quality after harvesting is also connected with chlorophyll degradation in green spears and anthocyanin synthesis in white spears, which occurs due to light exposure and temperature changes [4]. Furthermore, water loss and changes in ascorbic acid content, which influence total antioxidant activity decreases, occur in asparagus after harvesting [5, 6]. All of these quality changes and decay of asparagus can be reduced by cold storage and modified atmosphere packaging, MAP [7-9]. The recommended gas composition for plants with high transpiration rate (including asparagus) is $5-14 \% \mathrm{CO}_{2}$ and $3-21 \% \mathrm{O}_{2}[10]$.

Maintaining the quality of asparagus is possible via active packaging with ethylene-vinyl alcohol copolymer (EVOH) layers. This packaging material provides high oxygen barrier properties. Ethylene has hydrophobic and olefinic properties, and the hydroxyl substituent has hydrophilic properties [11]. However, EVOH is highly sensitive to humidity, which alters 
its resistance to $\mathrm{O}_{2}$ permeability [12]. Therefore, EVOH material is often combined by coextrusion with other polymeric materials, such as PP and PE, to increase barrier properties, as well as water-resistant polymers [13]. Packaging materials containing EVOH have high mechanical resistance to stretching and punching, and are less permeable to fumigants compared to other packaging films, such as HDPE and LDPE [14, 15]. Furthermore, high barrier films strongly affect the gas composition, mainly low $\mathrm{O}_{2}$ and high $\mathrm{CO}_{2}$ concentrations, which can slow the transpiration rate and weight loss of products during storage [16]. The influence of MAP technique on the quality and shelf-life of asparagus has been widely described. EVOH-packaging film has been applied to extend the shelf-life of mushrooms [6], milk [17], high transpiring fruits [18], and white cheese [19]. However, there is a lack of studies concerning MAP with material based on $\mathrm{PP} / \mathrm{EVOH} / \mathrm{PE}$. Therefore, the aim of the present research is to evaluate the combined effect of MAP PP/EVOH/PE-based packaging material and storage temperature on the shelf-life of green and white asparagus spears.

\section{Materials and methods}

\section{Sample preparation}

White and green asparagus spears of the cultivar Gijnlim were freshly purchased from a local market $\left(52^{\circ} 13^{\prime} \mathrm{N} 20^{\circ}\right.$ $50^{\prime}$ E, Ozarow Mazowiecki, Poland) in central Poland. In the laboratory the asparagus spears were washed with cold water, air-dried, sorted according to EC quality standard class 1 (UN/ECE FFV-04), cut into $18 \mathrm{~cm}$ pieces (mean spear diameter of $1.9 \pm 0.4 \mathrm{~cm}$ ) and white and green spears were randomly separated into 6-8 spears (approx. $200 \mathrm{~g}$ ) for each sample. Asparagus pieces were packed on PP/EVOH/ PE trays (approximately $580 \mu \mathrm{m}$ thick) with a $10 \mu \mathrm{m}$ thick EVOH layer with two films: PP/PE with an oxygen transmission rate of $3000 \mathrm{~cm}^{3} / \mathrm{m}^{2} / 24 \mathrm{~h}$ and $\mathrm{PP} / \mathrm{EVOH} / \mathrm{PE}$ with an oxygen transmission rate of $2 \mathrm{~cm}^{3} / \mathrm{m}^{2} / 24 \mathrm{~h}$ at standard temperature and pressure, and packed with a Sealpac Traysealer M3 (Sealpac, Germany) machine. Tray dimensions were $187 \times 137 \times 50 \mathrm{~mm}$ for both white and green asparagus samples. Asparagus spears were packed under the following modified atmosphere packaging (MAP) conditions: $5 \% \pm$ $2 \% \mathrm{CO}_{2}, 15 \% \pm 2 \% \mathrm{O}_{2}$ and $80 \% \pm 2 \% \mathrm{~N}_{2}$. The trays were stored for 17 days at a relative humidity (RH) of approx. $90 \%$, under identical conditions, in the absence of light (Fig. 1). Three replicates were conducted for each of the packaging conditions and storage time. All parameters, such as gas composition, weight loss, color, shear force, and sensory analysis, were determined at the beginning and on the 6th, 10th, 14th and 17th day of storage.

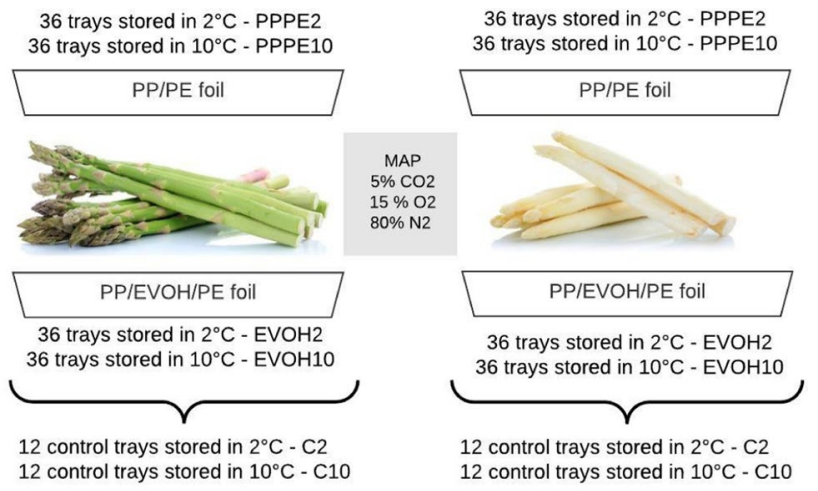

Fig. 1 Combination of samples and film type used for packaging green and white asparagus spears

\section{Gas analysis}

Gas composition analysis $\left(\mathrm{O}_{2}\right.$ and $\left.\mathrm{CO}_{2}\right)$ under all conditions was measured using a WITT Gasetechnik Analyzer (Witt-Gasetechnik, Model PA-S/P, Witten, Germany). The sensor needle pierced through the film with a specially fitted air-impermeable septum to measure the gas concentration in the headspace before opening the package. Oxygen and carbon dioxide concentrations were determined in triplicate for each tested container.

\section{Weight loss}

Weight loss (WL) was determined in triplicate by weighting asparagus spears at the beginning and on the last day of sampling. WL was expressed as a percentage of WL concerning the initial weight as follows: $\mathrm{WL} \%=\left(\mathrm{w}_{0}-\mathrm{w}_{1}\right.$ $\left./ \mathrm{w}_{0}\right) \times 100$; where $\mathrm{w}_{0}$ is the weight at the beginning; and $\mathrm{w}_{1}$ is the weight on the last storage day.

\section{Acidity and pH}

Green and white asparagus spears were separately minced and homogenized with $20 \mathrm{~mL}$ of distilled water for $180 \mathrm{~s}$, and $5 \mathrm{~g}$ was used for the measurement. The $\mathrm{pH}$ value was measured using the potentiometric method with a handheld pH meter (Model 205, Testo AG, Germany). The samples of each asparagus were titrated by adding $50 \mathrm{~mL}$ of $0.1 \mathrm{~N}$ $\mathrm{NaOH}$ with phenolphthalein as an indicator until the $\mathrm{pH}$ reached a value of 8.2 according to PN-EN 12147:2000 [20]. Acidity was measured in triplicate during storage for each day of sampling (and trays) and expressed as a citric acid percentage. 


\section{Texture}

The textural properties of green and white asparagus were determined as the shear force, which was measured using a Warner-Bratzler texturometer with load cell 500N and V-shaped blade (Model 5965, Instron, Canton, USA) with Bluehill@2 software. Texture parameters were determined by measuring the maximum shear force necessary to cut pieces the asparagus samples at the mid-section $(9.0 \mathrm{~cm}$ from the base) with a displacement speed of $200 \mathrm{~mm} / \mathrm{min}$. The tests were conducted in triplicate for each container, in which one speed test $(10 \mathrm{~mm} / \mathrm{min})$ was applied.

\section{Color}

The instrumental measurement of the color of asparagus was performed using the $L * a * b *$ color system as follows: $L^{*}$, lightness; $a^{*}$, color axis ranging from greenness $\left(-a^{*}\right)$ to redness $\left(+a^{*}\right)$; and $b^{*}$, color axis ranging from blueness $\left(-b^{*}\right)$ to yellowness $\left(+b^{*}\right)$. The color was measured using a Minolta chromameter (CR-400, Konica Minolta, Inc., Tokyo, Japan), which was calibrated using a white standard plate $\left(L^{*}=98.45, a^{*}=-0.10\right.$ and $\left.b^{*}=-0.13\right)$. A measuring head was $8 \mathrm{~mm}$ in diameter and D65 $(6500 \mathrm{~K}$ color temperature) illuminant. Color measurements were performed directly after opening the package. The determination of color parameters was performed by measuring 10 different randomly selected places on 10 asparagus surfaces. $\Delta \mathrm{E}$ was calculated using the following equation: $\Delta \mathrm{E}=\left[(\Delta \mathrm{L})^{2}+(\Delta \mathrm{a})^{2}+(\Delta \mathrm{b})^{2}\right]^{1 / 2}$; where $\Delta \mathrm{E}$ represents the degree of overall color change in comparison to color values of the control group.

\section{Sensory evaluation of asparagus}

The sensory characteristics of the asparagus samples were assessed using the quantitative response scale, following the procedure described in ISO standard 4131:2003 [21]. The sensory assessment was performed by trained panelists (ten members). The panelists fulfilled the requirements of ISO standard 8586:2012 [22]. Individual samples were placed in plastic containers and covered with lids. The samples were evaluated for firmness, color, odor and hardness (by hand) [23], on the following verbally anchored 5-point squared scale with interval spacing. These attributes were used for sensory analyses, which are shown in Table 1. A score of 2 was considered borderline acceptability. Samples were given to the panelists in random order ( $30 \mathrm{~g}$ each, row), and were encoded with 3-digit codes.
Table 1 Quality scores and descriptors for sensory evaluation

\begin{tabular}{ll}
\hline Scale & Description \\
1 & Very bad quality, unfresh spears \\
2 & Bad quality, untypical odor, no turgor \\
3 & Medium quality, typical odor and color \\
4 & Good quality, fresh, small color and texture changes \\
5 & Excellent quality, fresh, no color and texture changes \\
\hline
\end{tabular}

\section{Statistical analysis}

All experiments were performed in triplicate (except for color measurement, which was performed in 10 replicates), and average values with standard deviation were calculated. The significant differences were compared using one-way ANOVA and Tukey's post hoc test $(\alpha=0.05)$. To determine the overall impact of all factors on the chosen indexes, multifactorial analysis of variance was performed. Analyses were conducted using Statistica Software (version 12.0; Tulsa, USA).

\section{Results}

\section{Gas analysis}

Three factors, including storage time, temperature and asparagus type, had a significant impact on changes in the atmosphere composition in the packages (Figs. 2, 3). These changes in atmospheric composition were observed both in $\mathrm{PP} / \mathrm{PE}$ and PP/EVOH/PE packaging. The increase in $\mathrm{CO}_{2}$ in green asparagus packaged in PPPE10 was faster than in EVOH10. The lowest $\mathrm{CO}_{2}$ increase was observed in EVOH2 followed by PPPE2. As expected, the highest $\mathrm{O}_{2}$ decrease was found in PPPE10 and the lowest decrease in PPPE2. The total $\mathrm{O}_{2}$ consumption occurred after 17 days of storage, where the $\mathrm{CO}_{2}$ content increased to $42 \%(\mathrm{EVOH} 2)$ and $57.2 \%$ (PPPE10). In white asparagus, the fastest increase of $\mathrm{CO}_{2}$ occurred in EVOH10 (up to $60 \%$ ), indicating that white asparagus had higher transpiration than green asparagus. Moreover, cold storage possessed the lowest $\mathrm{CO}_{2}$ increase in PPPE2 (up to 45\%). In PPPE2, total $\mathrm{O}_{2}$ consumption occurred after 17 days of storage, while EVOH allowed for a partial slowdown of the breathing process.

\section{Weight loss}

As shown in Table 2, the highest WL for green and white asparagus was observed in $\mathrm{C} 10$ and $\mathrm{C} 2$. In contrast, the lowest WL was observed in EVOH2 (weight loss of $0.2 \%$ and $1.7 \%$ for green and white asparagus, respectively). WL was more dramatic using PPPE2 packaging with $1.3 \%$ and $9.5 \%$ 
Fig. 2 Oxygen and carbon dioxide concentrations of green asparagus packed in two different layers and stored at two different temperatures $2{ }^{\circ} \mathrm{C}$ and $10{ }^{\circ} \mathrm{C}$ for up to 17 days. Values followed by different small letters $(\mathrm{a}, \mathrm{b}, \mathrm{c})$ are significantly different $(\mathrm{p} \leq 0.05)$. Values are means of three replicates \pm standard deviation
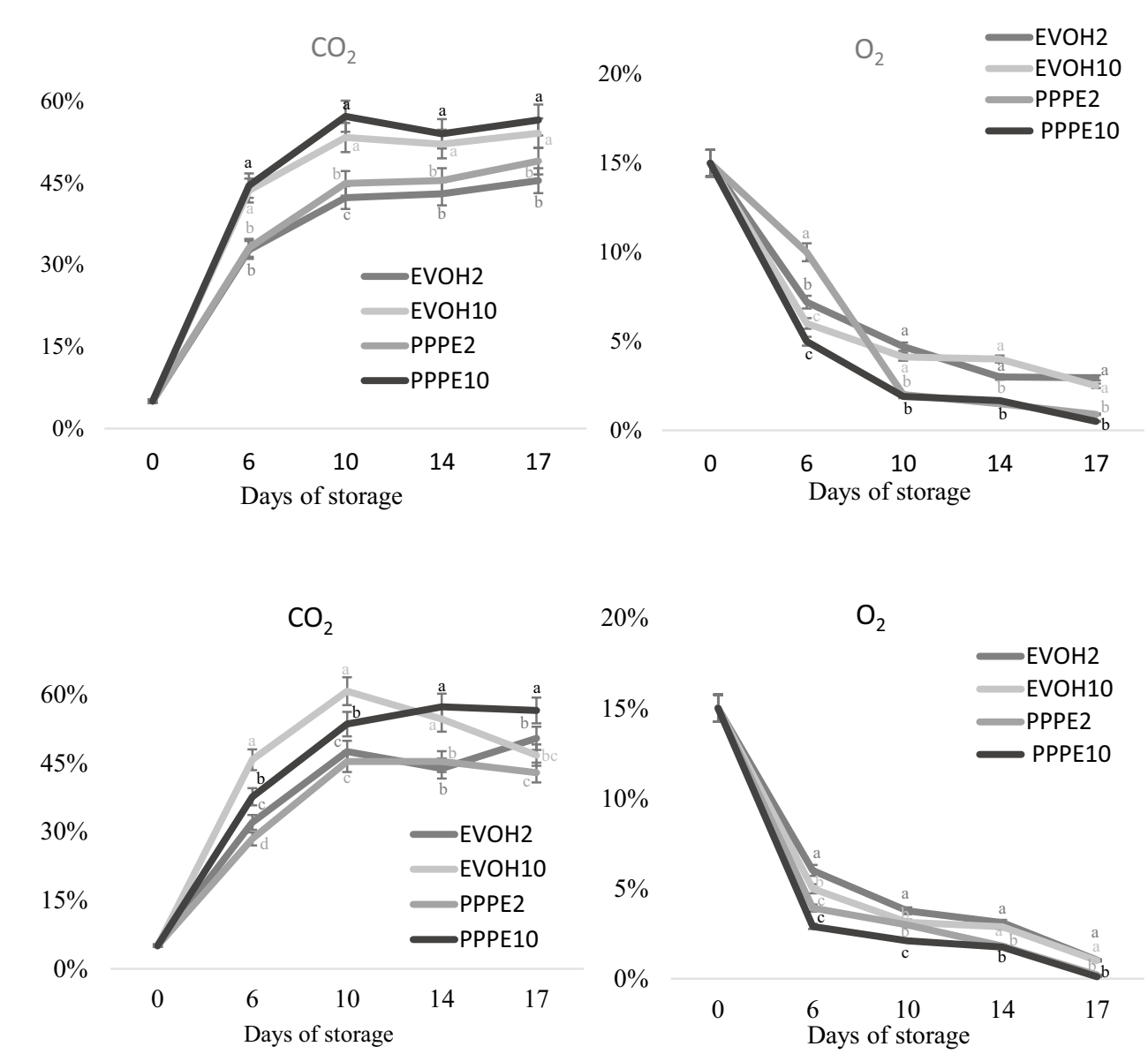

Fig. 3 Oxygen and carbon dioxide concentrations of white asparagus packed in two different layers and stored at two different temperatures $2{ }^{\circ} \mathrm{C}$ and 10 ${ }^{\circ} \mathrm{C}$ for up to 17 days. Values followed by different small letters $(\mathrm{a}, \mathrm{b}, \mathrm{c})$ are significantly different $(\mathrm{p} \leq 0.05)$. Values are means of three replicates \pm standard deviation for green and white asparagus, respectively. Therefore, WL was greater for white asparagus and higher barrier EVOH films were more suitable for vegetables with high respiration rate.

\section{Acidity and pH}

Table 2 shows the acidity and $\mathrm{pH}$ analysis results of white and green asparagus during postharvest storage. The temperature, time and package type had a significant influence on the acidity (Table 3). Fresh white and green asparagus had an initial acidity of $0.039 \%$ and $0.042 \%$, respectively. During storage, the largest increase in acidity was observed for $\mathrm{C} 2$ and $\mathrm{C} 10$. The use of MAP led to a less intense acidity increase in the spears. The applied type of packaging had an impact on acidity, where the asparagus packaged in EVOH had lower acidity than those in PPPE. The $\mathrm{pH}$ decreased significantly during the storage time for each sample. The initial $\mathrm{pH}$ values of fresh green and white asparagus were 6.10 and 5.65, respectively. The smallest $\mathrm{pH}$ change was obtained with EVOH packaging. For green and white asparagus stored in $\mathrm{EVOH} 2$, the $\mathrm{pH}$ values decreased to 5.79 and 5.72, respectively, during 17 days of storage, while stored in PPPE2, the $\mathrm{pH}$ values decreased to 5.59 and 5.61, respectively.

\section{Texture}

The results of the cutting force in the present study are shown in Table 4. Statistical analysis showed a significant impact of temperature, asparagus type, storage time and packaging on the hardness of asparagus (Table 3). The initial hardness values of green and white asparagus were approx. 41.23 and $48.25 \mathrm{~N}$, respectively. The lowest and highest increase of hardness for green asparagus during storage was observed in $\mathrm{EVOH} 2$ and $\mathrm{C} 10$, respectively. This trend was also observed for white asparagus stored in $\mathrm{EVOH}$ packaging, and the increase of hardness in EVOH packaging was less than in PP/PE packaging.

\section{Lightness and change of color}

Time, asparagus type, and packing method altered $L^{*}$ value of white and green asparagus during storage (Table 4). A rapid darkening of white asparagus in $\mathrm{C} 2$ and $\mathrm{C} 10$ was observed after 10 days of storage (79.12 and 77.54, respectively), while the color of $\mathrm{C} 2$ and $\mathrm{C} 10$ green spears remained 


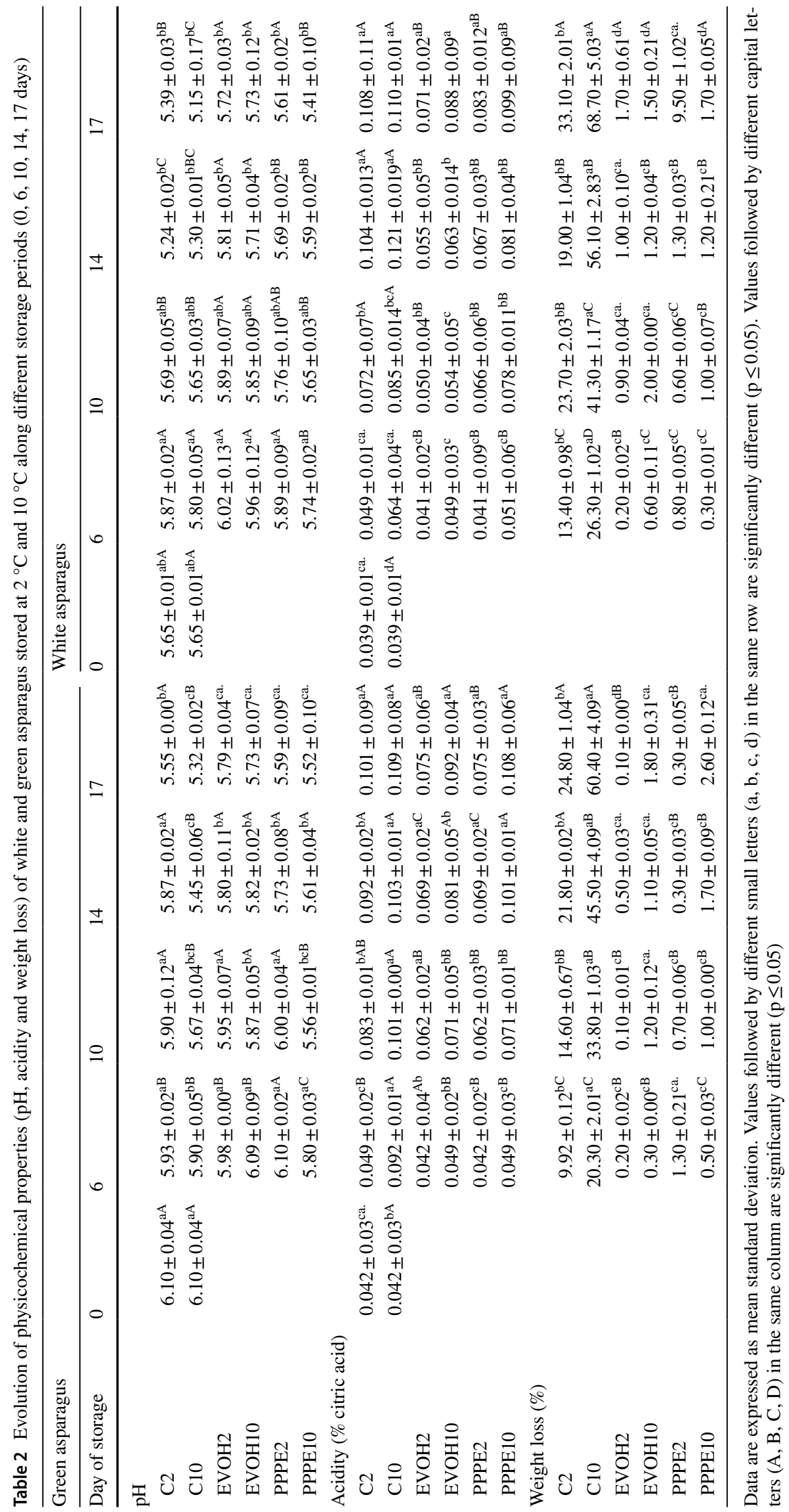


Table 3 Results of the variance analysis

\begin{tabular}{llllll}
\hline$\Delta$ & & & & & \\
\hline Factor & $\mathrm{L} *$ & $\Delta \mathrm{E}$ & Texture & Acidity & Loss weight \\
\hline $\mathrm{ST}$ & $*$ & $*$ & $* * *$ & $* * *$ & $* * *$ \\
$\mathrm{~T}$ & $\mathrm{~ns}$ & $\mathrm{~ns}$ & $*$ & $* *$ & $\mathrm{~ns}$ \\
$\mathrm{~A}$ & $* * *$ & $\mathrm{~ns}$ & $* *$ & $\mathrm{~ns}$ & $* *$ \\
$\mathrm{P}$ & $* *$ & $* * *$ & $*$ & $* * *$ & $* * *$ \\
$\mathrm{~T} \times \mathrm{A}$ & $\mathrm{ns}$ & $\mathrm{ns}$ & $\mathrm{ns}$ & $\mathrm{ns}$ & $* * *$ \\
$\mathrm{ST} \times \mathrm{P}$ & $\mathrm{ns}$ & $* * *$ & $\mathrm{~ns}$ & $* * *$ & $* * *$ \\
$\mathrm{ST} \times \mathrm{P} \times \mathrm{A}$ & $*$ & $* *$ & $\mathrm{~ns}$ & $\mathrm{~ns}$ & $\mathrm{~ns}$ \\
\hline
\end{tabular}

Effect of time storage (ST), temperature (T), type of asparagus (A), and package $(\mathrm{P})$ on color $\left(\mathrm{L}^{*}\right)$, color change $(\Delta \mathrm{E})$, hardness, acidity and loss weight

$n s$ not significant

$* \mathrm{p} \leq 0.05, * * \mathrm{p} \leq 0.01, * * * \mathrm{p} \leq 0.001$

constant on each measurement day. The color changes of asparagus were stronger in spears stored at $10{ }^{\circ} \mathrm{C}$ than those at $2{ }^{\circ} \mathrm{C}$. An increase of $\Delta \mathrm{E}$ value indicated greater differences in the color ratio to the reference sample. White asparagus showed higher value changes in $\mathrm{EVOH}$ packaging (1.7 to 7.1 ), indicating significant change. Smaller changes of $L^{*}$ and $\Delta \mathrm{E}$ were observed at $2{ }^{\circ} \mathrm{C}$. The $L^{*}$ value of green asparagus showed a substantial change according to storage time and type of packaging. However, in the present study, greening of green asparagus was noted, except for spears packaged in PPPE2, whose color suddenly changed after 17 days.

\section{Sensory analysis}

Scores for firmness, color, hardness, and odor for fresh green and white asparagus stored in $\mathrm{PP} / \mathrm{EVOH} / \mathrm{PE}$ and $\mathrm{PP} / \mathrm{PE}$ packages are shown in Supplementary Data 1. The degree of tip coloration (purple color) in white asparagus was investigated. The value of sensory features showed a negative decrease toward storage time and type of package. The type of package and MAP dramatically impacted the appearance during storage. Regardless of package type, asparagus stored at $2{ }^{\circ} \mathrm{C}$ was characterized by higher scores than asparagus stored at $10{ }^{\circ} \mathrm{C}$. In the case of green asparagus stored in EVOH2 decreased slower than asparagus stored in PPPE2. Moreover, the odor score of green asparagus after 6 days of storage in EVOH was less than that in PPPE, 4.21 and 4.00 , respectively. The results obtained for white asparagus showed a similar trend for firmness and color. Asparagus stored in $\mathrm{EVOH} 2$ had the lowest decrease of firmness (from 5.0 to 3.78 ) and color (from 4.8 to 3.50 ) during storage compared to PPPE2 samples, which varied from 5.0 to 1.0 for firmness and 4.8 to 2.0 for color. Based on the acceptable score of 2.0, only asparagus in $\mathrm{EVOH} 2$ could be stored for
17 days. Without any packaging, the sensory analysis scores decreased more intensely, limiting the stored time to only 6 days according to the acceptable score. Additionally, the purple tip coloration in white asparagus was investigated. In EVOH packaging, the increase of coloration was less than that in PPPE sample.

\section{Discussion}

Minimally processed products are one of the most important segments in food retail. However, fresh-cut produce is more perishable to spoilage than whole produce. The processing operations involved in the preparation of vegetables induce synthesis of secondary metabolites and membrane disruption and increases respiration rates. Hence, the food chain of minimally processed products is restricted due to short shelf-life, rapid deterioration of components and microbial growth $[24,25]$. Changes in gas composition of packaging atmosphere can influence physical attributes, which are related to maintaining freshness of raw produce. For instance, when $\mathrm{O}_{2}$ concentration declines below the critical limit required for sustaining anaerobic respiration, fermentation would occur, resulting in the development of off-flavor compounds. Furthermore, high $\mathrm{CO}_{2}$ concentration can also have a negative effect on product quality by accelerating changes in color, firmness and increasing the solubilization of pectic compounds [26, 27]. In contrast, $\mathrm{CO}_{2}$ also has a minor suppression effect on the respiration of some fresh fruits and vegetables, which can help extend their shelf life. Also, $\mathrm{CO}_{2}$ reduces the sensitivity of plant tissues to the ripening hormone ethylene by $\mathrm{CO}_{2}$ concentration [28]

The presence of water in the raw material promotes the mold growth. The low concentration of $\mathrm{O}_{2}$ has no impact on mycotoxin formation in raw materials, while high levels of $\mathrm{CO}_{2}$ do not guarantee elimination of spoilage. According to other studies, the use of EVOH film possesses protective properties against water vapor and gas permeability [29-31]. The asparaguses respiration changes during the first 2 days of storage, which were determined as a crucial factor affecting raw material shelf-life. The use of PP/PE packaging foil together with MAP preserves with a constant ratio of gases $\left(15 \% \mathrm{O}_{2}, 5 \% \mathrm{CO}_{2}\right)$ during the first two days of storage. However, the results obtained in the current study show changes in gases ratio (increase of $\mathrm{CO}_{2}$ and decrease of $\mathrm{O}_{2}$ ) on the second day of storage. Previous reports have shown that PP/PE foil is the most airtight for processed green asparagus packed in MAP without $\mathrm{O}_{2}\left(\mathrm{CO}_{2} 30 \%\right.$ and $\mathrm{N}_{2} 70 \%$ ) over 30 days of storage at $4{ }^{\circ} \mathrm{C}$ [7]. Studies concerning shelf-life of green asparagus have found a comparable relationship between the atmosphere composition and temperature, which is in agreement with this current research. A higher temperature causes a greater drop in $\mathrm{O}_{2}$ content 


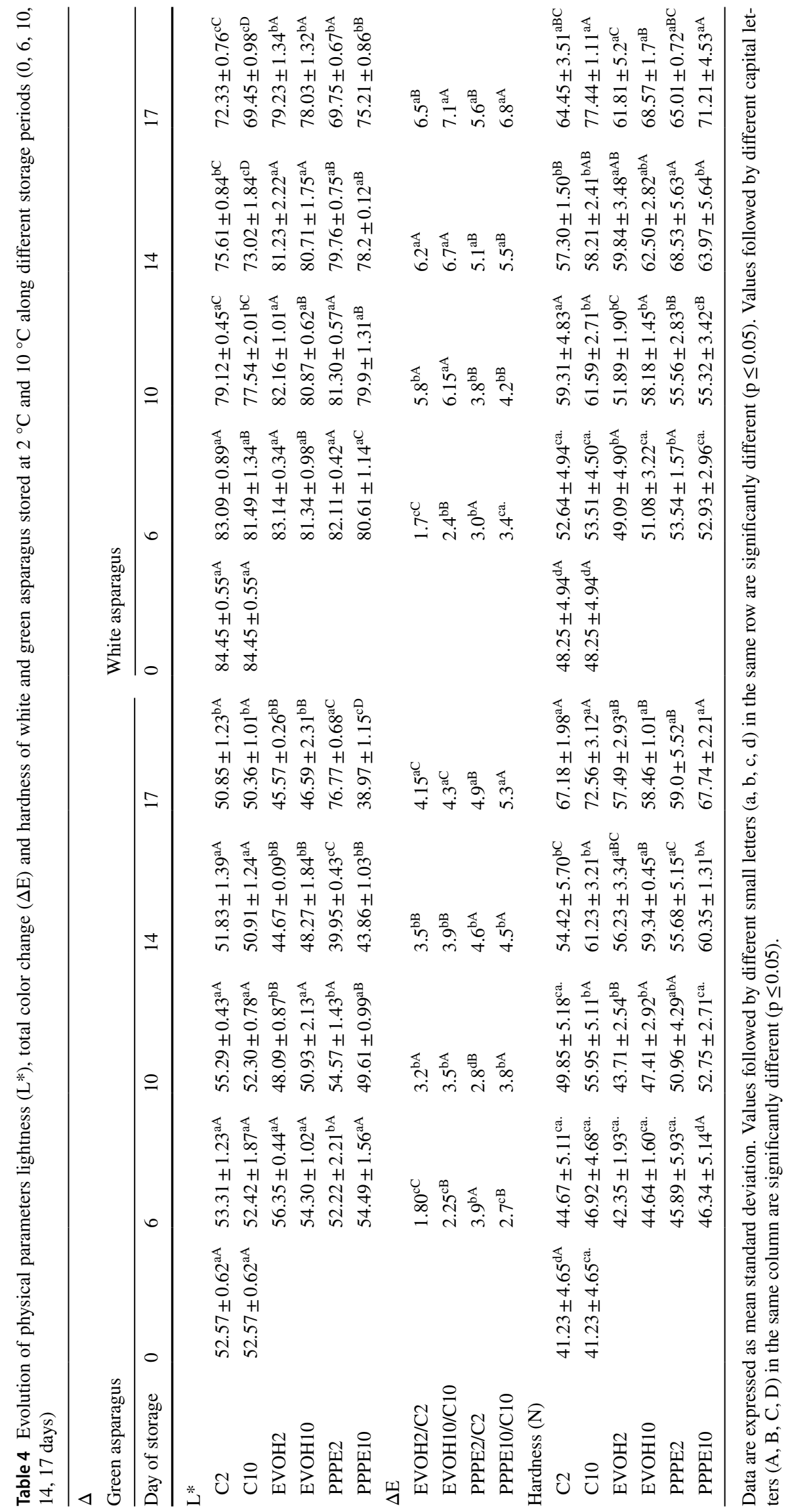


compared with cooler temperature [32]. A study on strawberry fruit displayed an intense drop in $\mathrm{O}_{2}$ and increase in $\mathrm{CO}_{2}$ during storage in EVOH-based packaging [33]. Bodbodak and Moshfeghifar [28] reported that residual amount of $0.5 \pm 0.2 \%$ of $\mathrm{O}_{2}$ after storage is necessary to avoid an anaerobic environment, thus preventing the growth of anaerobic bacteria, which is consistent with our results. A similar study on white asparagus shows that higher content of $\mathrm{CO}_{2}$ $\left(10 \% \mathrm{CO}_{2}\right.$ and $\left.17 \% \mathrm{O}_{2}\right)$ has no negative effect when stored at $20{ }^{\circ} \mathrm{C}$ [34].

The decrease in $\mathrm{pH}$ and higher acidity in PP/PE packaging are related to higher $\mathrm{CO}_{2}$ content in the package, leading to increase in carbonic acid concentration. Reports have confirmed the positive influence of MAP on stored asparagus by limiting the increase of acidity and decreasing $\mathrm{pH}$, which is in agreement with our results [32,33]. WL is an important indicator during postharvest storage, and quality indicator of the packing method. More than $8 \%$ of weight loss leads to reduced customer acceptability. The results obtained in this study indicate that WL is greater in white asparagus and higher barrier EVOH films are more suitable for vegetables with high respiration rate [5]. Asparagus WL is lower (1-3\%) during cold storage and in MAP packaging $[35,36]$. These results are consistent with those reported for other products with high respiration rate and packed in EVOH, including raspberry with WL of $0.5 \%$ and strawberry with WL of $0.9 \%$ [16]. Wang [37] stated that the primarily concentration of $60 \% \mathrm{CO}_{2}$ during storage of asparagus prevents WL. Both white and green asparagus stored at ambient temperature without packaging lost $4.85 \%$ of initial weight, while those packed in MAP lost $0.8 \%$ after 14 days of storage [7].

The effect of MAP on maintaining texture is usually related to the control of WL, previous studies have demonstrated that products with high WL have greater reduction in texture [38]. However, asparagus spears during storage become increasingly tough and fibrous, which is related to the degree of lignification of pericyclic fibers and subsequent increase in cell polymers [37]. The increase in hardness over time is more intense for white asparagus than green asparagus. However, due to EVOH strong barrier properties, the shelf-life of asparagus can be extended, and the lignification process minimized. Furthermore, the present study confirmed that fresh white asparagus has higher hardness values and that the lignification process occurs more rapidly than in green asparagus [5, 34, 39]. Albanese et al. [35] reported good hardness (acceptable by consumers) for untreated asparagus stored in the refrigerator for 5 days. Huyskens-Keil and Herppich [8] stated that high $\mathrm{CO}_{2}$ concentration reduces texture by inhibiting the synthesis of cell wall components, which can cause asparagus spear toughness, which in turn suppresses firming of asparagus spears. This is in agreement with studies that show high $\mathrm{CO}_{2}$ and low $\mathrm{O}_{2}$ concentrations inhibit the phenylalanine ammonia-lyase (PAL) activity, a key enzyme used in lignin synthesis [2]. Simón and Gonzalez-Fandos [40] showed no significant effect of any factors (time, temperature and film) on the texture of spears during storage in MAP. However, according to other studies, factors such as type of harvesting season, climate and temperature $24 \mathrm{~h}$ before collection are important for maintaining the texture of asparagus [32].

The color parameter of vegetables is the first visible quality point assessed by consumers, and indicates putrefying time [41]. Asparagus has a patchy color with browning during storage time. Lower asparagus parts are lighter than higher parts, which are typical properties of green spears. Color change along the edible portion indicates the effect triggered by the cellular respiration process and is commonly associated with breakdown of cellular chloroplasts, chromoplasts, natural pigments and is a major factor in determining the quality of asparagus spears [42]. Darkening of white asparagus is associated with the biosynthesis of anthocyanins, which are generated in the apical part [43], while the color change in green asparagus is more intense due to degradation of chlorophyll [35]. Color change is also related to enzymatic browning, which is associated with the activity of the enzyme polyphenol oxidase, ascorbic acid oxidase, and glycolic acid oxidase [27]. Numerous reports have shown the advantage of low or high $\mathrm{O}_{2} / \mathrm{CO}_{2}$ concentrations for maintaining the color attributes of asparagus [5, 27, 32, 40]. Tzoumaki et al. has shown that high $\mathrm{CO}_{2}$ content and low $\mathrm{O}_{2}$ content have a positive effect on the inhibition of anthocyanin synthesis [44]. The color changes of green asparagus after 6 days of storage have been reported by Sergio et al. [7]. According to Cruz-Romero et al. [45], the $\Delta E$ value of green asparagus varies from 1.8 to 5.3 , indicating significant change during storage. In contrast, Nindo et al. [46] reported that the $L^{*}$ of raw green asparagus is 40.2 , which is much lower than our results. These differences between color coordinates may be due to the method of raw material measurement, as well as asparagus cultivar, and growing conditions [4].

Obtained results of sensory analysis in the current study are in agreement with results reported by Villanueva et al. [32] and Tzoumaki et al. [44]. The change of odor in the investigated samples is related to high barrier film and anaerobic conditions inside, thus formation of off-odor compounds was examined [23]. According to Yoon et al. [47] the quality of asparagus packed in different oxygen transmission rate EVOH film (from 10 to $100 \mathrm{~cm}^{3} / \mathrm{m}^{2} / 24 \mathrm{~h}$ ) based on sensory analysis showed that the least off-odor was detected in the highest transmission rate film, while the highest firmness of spear was observed in the lowest transmission rate film, which is not consistent with current research. 


\section{Conclusion}

Packaging in MAP with an appropriate ratio of gases and EVOH layer may extend the shelf-life of asparagus. The results showed that the use of $\mathrm{EVOH}$ with $5 \% \pm 2 \% \mathrm{CO}_{2}$, $15 \% \pm 2 \% \mathrm{O}_{2}$ and $80 \% \pm 2 \% \mathrm{~N}_{2}$ had a positive effect on $\mathrm{WL}$, acidity, $\mathrm{pH}$ value, color and texture quality for up to 17 days of storage for green asparagus and 10 days of storage for white asparagus as compared to unpackaged spears. Decreasing the $\mathrm{O}_{2}$ level and increasing the $\mathrm{CO}_{2}$ level may reduce respiration and decelerate various compositional changes associated with storage. Each asparagus type showed the best quality when stored at $2{ }^{\circ} \mathrm{C}$. According to the obtained results, prolonged freshness can be provided by combining low cooling temperature and packaging material containing an EVOH layer.

Acknowledgements This research did not receive any specific grant from funding agencies in the public, commercial, or not-for-profit sectors.

Open Access This article is licensed under a Creative Commons Attribution 4.0 International License, which permits use, sharing, adaptation, distribution and reproduction in any medium or format, as long as you give appropriate credit to the original author(s) and the source, provide a link to the Creative Commons licence, and indicate if changes were made. The images or other third party material in this article are included in the article's Creative Commons licence, unless indicated otherwise in a credit line to the material. If material is not included in the article's Creative Commons licence and your intended use is not permitted by statutory regulation or exceeds the permitted use, you will need to obtain permission directly from the copyright holder. To view a copy of this licence, visit http://creativecommons.org/licenses/by/4.0/.

\section{References}

1. J.M. Fuentes-Alventosa, G. Rodríguez-Gutiérrez, S. JaramilloCarmona, J.A. Espejo-Calvo, R. Rodríguez-Arcos, J. Fernández-Bolaños, A. Jiménez-Araujo, Effect of extraction method on chemical composition and functional characteristics of high dietary fibre powders obtained from asparagus by-products. Food Chem. 113(2), 665-671 (2009)

2. P.K. Bhowmik, T. Matsui, T. Ikeuchi, H. Suzuki, Changes in storage quality and shelf life of green asparagus over an extended harvest season. Postharvest Biol. Technol. 26(3), 323-328 (2002)

3. B. Chitrakar, M. Zhang, B. Adhikari, Asparagus (Asparagus officinalis): processing effect on nutritional and phytochemical composition of spear and hard-stem byproducts. Trends Food Sci. Technol. 93, 1-11 (2019)

4. T. Li, M. Zhang, Effects of modified atmosphere packaging (MAP) with a silicon gum film window on the quality of stored green asparagus (Asparagus officinalis L.) spears. LWT Food Sci. Technol. 60(2), 1046-1053 (2015)

5. A.S. Siomos, E.M. Sfakiotakis, C.C. Dogras, Modified atmosphere packaging of white asparagus spears: composition, color and textural quality responses to temperature and light. Sci. Hortic. 84(1-2), 1-13 (2000)
6. G. Rux, P.V. Mahajan, M. Geyer, M. Linke, A. Pant, S. Saengerlaub, O.J. Caleb, Application of humidity-regulating tray for packaging of mushrooms. Postharvest Biol. Technol. 108, 102-110 (2015)

7. L. Sergio, V. Cantore, L. Spremulli, L. Pinto, F. Baruzzi, D. Di Venere, Effect of cooking and packaging conditions on quality of semi-dried green asparagus during cold storage. LWT Food Sci. Technol. 89, 712-718 (2018)

8. S. Huyskens-Keil, W.B. Herppich, High $\mathrm{CO}_{2}$ effects on postharvest biochemical and textural properties of white asparagus (Asparagus officinalis L.) spears. Postharvest Biol. Technol. 75, 45-53 (2013)

9. O.J. Caleb, P.V. Mahajan, F.A.-J. Al-Said, U.L. Opara, Modified atmosphere packaging technology of fresh and fresh-cut produce and the microbial consequences-a review. Food Bioprocess Technol. 6(2), 303-329 (2013)

10. S. Mangaraj, T.K. Goswami, Modified atmosphere packaging for fruits and vegetables for extending shelf life: a revive. Fresh Prod. 3(1), 1-31 (2009)

11. E.M. Mateo, J.V. Gómez, I. Domínguez, J.V. Gimeno-Adelantado, R. Mateo-Castro, R. Gavara, M. Jiménez, Impact of bioactive packaging systems based on EVOH films and essential oils in the control of aflatoxigenic fungi and aflatoxin production in maize. Int. J. Food Microbiol. 254, 36-46 (2017)

12. R. Gavara, R. Catalá, G.L. Carballo, J.P. Cerisuelo, I. Dominguez, V. Muriel-Galet, P. Hernandez-Muñoz, Use of EVOH for food packaging applications, in Reference Module in Food Science (Elsevier, 2016), pp. 1-6

13. J.-H. Wu, C.-P. Wu, M.C. Kuo, Y. Tsai, Characterization and properties of reactive poly (lactic acid)/ethylene-vinyl alcohol copolymer blends with chain-extender. J. Polym. Environ. 40, 1204-1214 (2016)

14. S. Gao, B.D. Hanson, R. Qin, D. Wang, S.R. Yates, Comparisons of soil surface sealing methods to reduce fumigant emission loss. J. Environ. Qual. 40(5), 1480-1487 (2011)

15. I.S. Arvanitoyannis, A.C. Stratakos, Application of modified atmosphere packaging and active/smart technologies to red meat and poultry: a review. Food Bioprocess Technol. 5(5), 1423-1446 (2012)

16. G. Giovanelli, S. Limbo, S. Buratti, Effects of new packaging solutions on physico-chemical, nutritional and aromatic characteristics of red raspberries (Rubus idaeus L.) in postharvest storage. Postharvest Biol. Technol. 98, 72-81 (2014)

17. H. Panfil-Kuncewicz, A. Kuncewicz, A. Puławski, Wpływ opakowania na trwałość mleka spożywczego. ŻYWNOŚĆ Nauka Technol. Jakość 2(63), 5-13 (2009)

18. S.A. Fennimore, H.A. Ajwa, Totally impermeable film retains fumigants, allowing lower application rates in strawberry. Calif. Agric. 65(4), 211-215 (2011)

19. I. Dmytrów, K. Kryża, K. Dmytrów, S. Lisiecki, Wpływ opakowania na wybrane cechy jakościowe sera twarogowego kwasowego przechowywanego w warunkach chłodniczych. ŻYWNOŚĆ Nauka Technol. Jakość 1(50), 64-76 (2007)

20. Polish Standard Committee, Polish Standard, PN-EN 12147:2000. Fruit and Vegetable Juices-Determination of Titrable Acidity (Polish Standard Committee, 2000), pp. 1-4

21. Polish Standard Committee, Polish Standard. PN ISO 4121:2003 Sensory Analysis-Guidelines for the Use of Quantitative Response Scales. Polish Standard Committee, 2003), pp. 1-9

22. Polish Standard Committee, Polish Standard. EN ISO 8586:2012 Sensory Analysis. General Guidelines for the Selection, Training and Monitoring of Selected Assessors and Expert Sensory Assessors (Polish Standard Committee, 2012), pp. 1-28 
23. R. Sothornvit, P. Kiatchanapaibul, Quality and shelf-life of washed fresh-cut asparagus in modified atmosphere packaging. LWT Food Sci. Technol. 42(9), 1484-1490 (2009)

24. R.B. Waghmare, U.S. Annapure, Combined effect of chemical treatment and/or modified atmosphere packaging (MAP) on quality of fresh-cut papaya. Postharvest Biol. Technol. 85, 147-153 (2013)

25. Z.A. Belay, O.J. Caleb, U.L. Opara, Influence of initial gas modification on physicochemical quality attributes and molecular changes in fresh and fresh-cut fruit during modified atmosphere packaging. Food Packag. Shelf Life 21, 100359 (2019)

26. G.H. Teixeira, L.C. Júnior, L.A.S. Ferraudo, J.F. Durigan, Quality of guava (Psidium guajava L. cv. Pedro Sato) fruit stored in low $\mathrm{O}_{2}$ controlled atmospheres is negatively affected by increasing levels of $\mathrm{CO}_{2}$. Postharvest Biol. Technol. 111, 62-68 (2016)

27. X. Li, Y. Jiang, W. Li, Y. Tang, J. Yun, Effects of ascorbic acid and high oxygen modified atmosphere packaging during storage of fresh-cut eggplants. Food Sci. Technol. Int. 20(2), 99-108 (2014)

28. S. Bodbodak, M. Moshfeghifar, Advances in modified atmosphere packaging of fruits and vegetables, in Eco-friendly Technology for Postharvest Produce Quality, pp. 127-183 (2016). https://doi. org/10.1016/B978-0-12-804313-4.00004-9

29. J.P. Cerisuelo, R. Gavara, P. Hernandez-Munoz, Natural antimicrobial-containing EVOH coatings on PP and PET films: functional and active property characterization. Pack. Technol.Sci. 27, 901-920 (2014)

30. R. Heras-Mozos, V. Muriel-Galet, G. Lopez-Carballo, R. Catala, Active EVOH/PE bag for sliced pan loaf based on garlic as antifungal agent and bread aroma as aroma corrector. Food Pack. Shelf Life 18, 125-130 (2018)

31. R. McWatters, K.R. Rowe, Barrier permeation properties of EVOH thin-film membranes under aqueous and non-aqueous conditions. Geotext. Geomembr. 46, 529-541 (2018)

32. M.J. Villanueva, M.D. Tenorio, M. Sagardoy, A. Redondo, M.D. Saco, Physical, chemical, histological and microbiological changes in fresh green asparagus (Asparagus officinalis, L.) stored in modified atmosphere packaging. Food Chem. 91(4), 609-619 (2005)

33. C. Caner, M.S. Aday, Extending the quality of fresh strawberries by equilibrium modified atmosphere packaging. Eur. Food Res. Technol. 227(6), 1575-1583 (2008)

34. W.B. Herppich, S. Huyskens-Keil, Cell wall biochemistry and biomechanics of harvested white asparagus shoots as affected by temperature. Ann. Appl. Biol. 152, 377-388 (2008)

35. D. Albanese, L. Russo, L. Cinquanta, A. Brasiello, M. Di Matteo, Physical and chemical changes in minimally processed green asparagus during cold-storage. Food Chem. 101(1), 274-280 (2007)

36. L. Tiehua, Z. Min, Effects of modified atmosphere package (MAP) with a silicon gum film window on the quality of stored green asparagus (Asparagus officinalis L.) spears. LWT Food Sci. Technol. 60, 1046-1053 (2015)

37. J. Wang, Effect of ultrasound treatment on microbial inhibition and quality maintenance of green asparagus during cold storage. Ultrason. Sonochem. 58, 104631 (2019)

38. M. Jouki, N. Khazaei, Effect of low-dose gamma radiation and active equilibrium modified atmosphere packaging on shelf life extension of fresh strawberry fruits. Food Packag. Shelf Life 1(1), 49-55 (2014)

39. R. Rodríguez, S. Jaramillo, R. Guillén, A. Jiménez, J. Fernández-Bolaños, A. Heredia, Cell wall phenolics of white and green asparagus. J. Sci. Food Agric. 85(6), 971-978 (2005)

40. A. Simón, E. Gonzalez-Fandos, Influence of modified atmosphere packaging and storage temperature on the sensory and microbiological quality of fresh peeled white asparagus. Food Control 22(3-4), 369-374 (2011)

41. L. Mastropasqua, P. Tanzarella, C. Paciolla, Effects of postharvest light spectra on quality and health-related parameters in green Asparagus officinalis L. Postharvest Biol. Technol. 112, 143-151 (2016)

42. X.R. Yin, X.L. Xie, X.J. Xia, J.G. Yu, I.B. Ferguson, J.J. Giovannoni, Involvement of an ethylene response factor in chlorophyll degradation during citrus fruit degreening. Plant J. 86(5), 403-412 (2016)

43. F.B. Flores, J. Oosterhaven, M.C. Martínez-Madrid, F. Romojaro, Possible regulatory role of phenylalanine ammonia-lyase in the production of anthocyanins in asparagus (Asparagus officinalis L.). J. Sci. Food Agric. 85, 925-930 (2005)

44. M.V. Tzoumaki, C.G. Biliaderis, M. Vasilakakis, Impact of edible coatings and packaging on quality of white asparagus (Asparagus officinalis, L.) during cold storage. Food Chem. 117(1), 55-63 (2009)

45. M. Cruz-Romero, A.L. Kelly, J.P. Kerry, Effects of high-pressure and heat treatments on physical and biochemical characteristics of oysters (Crassostrea gigas). Innov. Food Sci. Emerg. Technol. 8(1), 30-38 (2007)

46. C. Nindo, T. Sun, S. Wang, J. Tang, J. Powers, Evaluation of drying technologies for retention of physical quality and antioxidants in asparagus (Asparagus officinalis, L.). LWT Food Sci. Technol. 36(5), 507-516 (2003)

47. H.S. Yoon, I.-L. Choi, H.-M. Kang, Different oxygen transmission rate packing films during modified atmosphere storage: effects on asparagus spear quality. Korean J. Hortic. Sci. Technol. 35(3), 314-322 (2017)

Publisher's Note Springer Nature remains neutral with regard to jurisdictional claims in published maps and institutional affiliations. 